\title{
RELATIONSHIP BETWEEN CREATIVITY AND SELF-CONCEPT ON STUDENTS' ACADEMIC ACHIEVEMENT IN BORNO STATE COLLEGE OF EDUCATION: IMPLICATIONS FOR COUNSELLING
}

\author{
U. GONI AND PROF. M. U. TAMBAWAL
}

\begin{abstract}
This is a correlational study design to determine the relationship between creativity and self-concept on students' academic achievement in Colleges of Education in Borno State. The study set three research objectives and tested three research hypotheses. For the purpose of this study, two main approaches were used; cognitive approaches were applied to creativity while humanistic approaches were also applied to self-concept. The uniqueness of this study lies in the area where Xiaxia (1999) investigated gender differences in their examination of the relationship between creativity and academic achievement. While this study focuses on creativity and self-concept on students' academic. achievement, the target population for this study was 4,517 students who have registered in NCE awarding institutions in Borno State. Purposive sampling technique was used to select two Colleges of Education in Borno State, the stratified random sampling procedure was also employed to select 322 participants 186 students from 351 NCE III students' from Kashim Ibrahim College of Education, Maiduguri and 136 students from 210 NCE III students from Umar Ibn Ibrahim College of Education, Science and Technology, Bama. Students' Creativity Test (SCT) and Students' Self-concept Scale (SUSS) was used by the researchers. Pearson 'r' was used to test the hypotheses raised in this study. The results indicated a very low and positive relationship between creativity and self-concept among students of Colleges of Education, the results indicated a high and positive relationship between the two variables and the results also indicated a very high and positive relationship between the two variables. Based on the results obtained the following Counselling strategy are suggested; there is the need for counselling personnel to guide the students on how well they should improve their creativity and self-concept through enhancing the students' imaginary thinking and improvised their needs by the authority.
\end{abstract}

\section{Background of the study}

The world is becoming more and more competitive. Quality of performance has become the key factor for personal progress. Parents desire that their children climb ladder of performance to as high a level as possible. This desire for high level of achievement puts a lot of pressure on students, teachers, and schools and in general the education system itself. In fact, it appears as if the whole system of education revolves round the academic achievement of students, though various other outcomes are also expected from the system. Thus a lot of time and effort of the schools are used for helping students to achieve better in their scholastic endeavors. The importance of scholastic and academic achievement has raised important questions for educational researcher (Nuthanap, 2007). Both American and British psychologists have used the term "creativity" synonymously with 'imagination', 'originality', divergent thinking', 'inventiveness', (Child 1977). Guildford (1959) saw creativity as divergent thinking. He said the kind that goes off in different directions. Such thinking is less restricted by given facts; it permits changes of direction in problem solving and leads to diversity of creative thinking as merely an aspect of intelligence or relational thinking. 
- Definitions of creativity seem to fall into four categories according to Kneeler (1965). Creativity may be considered from the standpoint of the person who creates, that is, in terms of psychology and temperament, including personal attitudes, habits, and values. It may also be explained by way of the mental process, motivation, perception, learning, thinking and communicating, a third definition focus on environmental and cultural influences. Finally, creativity may be understood in terms of its products, such as theories, inventions, paintings, carvings, and poems.

Okoh (1983) defines creativity as the ability to bring into being or form something out of nothing or by force of the imagination. Its essence is novelty as well as relevance to a particular situation. This creative novelty springs largely from rearrangement of existing knowledge. What the creative person does is to re-create nature by searching for and meaning in our experience. Creativity is fundamental to self-reliance, the more selfreliance a person becomes, the better the quality of his/her life, family, community, and society at large. Creativity enables human beings to get the most out of life experiences and resources. Creativity produces actionable ideas, new concepts, new designs and new opportunities, while innovations add values to new product in line with this, students with high sense of creativity always achieved his/her educational goals and aspirations. According to Akinboye (2003), without creativity, a person will not be able to access the fullness of information and resources available but is locked up in old habit, structure, patterns, concepts, and perceptions. This is why creativity is referred to as general perception, constructive and design thinking plus innovation should form the basis of any education for suitable development. Sandburg and Lubart (1996) describe creativity as the confluence of intellectual activity, knowledge, motivation, thinking styles, personality and environment. Therefore, students with positive creativity tend to perform very well in his/her examinations.

As an individual grows and develops, he learns, not only about the world about himself and his place in it, but also about himself. Each person lives with himself and hence, to some degree is always alone. No one can ever completely know the self-better than anyone else, although in the pursuit for understanding oneself and others there has developed much of human thought and philosophy, including psychology. Man has a long held in the hope of answering such question as: who am I? How did I come to be this way? And their logical consequence, the search for purpose; why am I? (Nadalmani, 2001).

The psychological construct, self-concept is essentially private even though it is in part translated into action by beliefs we express. Siơhu (1987) defines self-concept as those perceptions, beliefs, feelings, attitudes and values which the individual used in on describing him/herself. Personality is not a specific quality of a person's but a quality of his/her behavior. How he/she behave depend upon how he/she feels about him/herself, about other people and about his/her relationship with them. These feelings make up his/her self-concept, what he /she thinks about him/herself as a person. A person's selfconcept is the fundamental core of his entire personality and determines the quality of behavior. 
According to Salawu (1998) 'self' has always been difficult to define with precision because it is used so frequently to reflect the overall constellation of a person's psychological characteristic an out-come usually referred to as an individual's personality. Tambawal (2001) in his study on self-concept and career maturity found positive relationship between the variables. These various definitions constitute the conceptual framework which guide the conduct of this study.

\section{Statement of problem}

The problem of poor academic achievement of students at the tertiary level of education, and particularly among the Nigerian Certificate of Education (NCE) students is a matter of serious concern to all stakeholders in the society. This is because the NCE graduates will be employed to teach at the primary and junior secondary school levels of education. In addition if the NCE students are performing badly there is the possibility that those taught by these students will perform badly too. The quality of education provided in any society and the nature of change effected by education are both dependent on the quality of teachers and by the effectiveness of their teaching.

In relation to creativity, the students could not directly relate what they teach with visual aids they are supposed to use. They could not improvise local materials in developing teaching aids such as sketches models and diagrams. They don't use various methods in teaching a topic of a subject. They usually don't use relevant materials in teaching the lesson. Some of them are mostly convergent in thinking that they don't think in various dimensions in seeing relationship of object and ideas while may be due to the fact that they had not got the orientation of seeing things in different dimensions. Transfer of learning is not demonstrated by them when they are teaching in the class, which is evident in the way they use a single method in teaching various topics and subjects instead of using various method in teaching a topic or subject.

On NCE studer t's self-concept, the researchers have the impression that many students of Colleges of Education have come from low income earning families. They lack enough money 'o support themselves in attaining their physiological, social, emotional and psychological needs. It implies therefore, some of them came to class without taking breakfast. Not all of them attend parties and other gathering for lack of dresses that they could use to attend parties or various occasions. When the need to contribute to the clubs and societies arises they failed to provide as required. This state of affairs makes the individual student socially withdrawn and develops poor self-concept about him. They seldom feel that they are not important as compared to their colleagues who possess good things of life. Therefore, the main thrust of study is to investigate relationship between creativity and self-concept, on academic achievement of students in Colleges of Education, implications for counselling.

\section{Objectives of the Study}

The objectives of the study were to determine if there is any relationship between: 
i. Creativity and self-concept of students in Colleges of Education Borno State

ii. Creativity and academic achievement of students in Colleges of Education in Borno State

iii. Self-concept and academic achievement of students in Colleges of Education in Borno State

\section{Research Questions}

The following research questions were set in this study to fine out:

i. If there is any relationship between creativity and self-concept of students in Colleges of Education Borno State

ii. If there is any relationship between creativity and academic achievement of students in Colleges of Education in Borno State

iii. If there is any relationship between self-concept and academic achievement of students in Colleges of Education in Borno State

\section{Research Hypotheses}

The following null hypotheses were tested in this study:

$\mathrm{Ho}_{1}$ : There is no significant relationship between creativity and self-concept of students inColleges of Education in Borno State

$\mathrm{Ho}_{2}$ : There is no significant relationship between creativity and academic achievement ofstudents in Colleges of Education in Borno State

$\mathrm{Ho}_{3}$ : There is no significant relationship between self-concept and academic achievement of students in Colleges of Education in Borno State

\section{Methodology}

The research design for this study was correlation design. Correlation design is a research design widely used to measure relationships between two or more variables (Tilley, 1994; Mallim \& Birch, 1997) and Cohen Morrison (2000). Reported that correlation allows for the study of behaviors in realistic settings and is suitable in predictive studies. Correlations are related not only to the correlation of the independent with the dependent variable but also to the inter correlations between the independent variable. The target population for this study was 4,517 students who have registered in NCE awarding institutions in Borno State. Purposive sampling technique was used to select two Colleges of Education in Borno State, the stratified random sampling procedure was also employed to select (322) participants 186 students from 351NCE III students' from Kashim Ibrahim College of Education, Maiduguri and 136 students from 210 NCE III students from Umar Ibn Ibrahim College of Education, Science and Technology, Bama. Students' Creativity Test (SCT) and Students' Self-concept Scale (SUSS) was used by the researchers. Pearson ' $r$ ' was used to test the hypotheses raised in this study. 
Results

$\mathrm{HO}_{1}$ : There is no significant relationship between creativity and self-concept of students in Colleges of Education in Borno State.

Table 1: Mean standard deviation and ' $r$ ' value of creativity and self-concept of students in Colleges of Education Borno State.

\begin{tabular}{llllllll}
\hline Variable & $\mathrm{N}$ & $\mathrm{X}$ & $\mathrm{SD}$ & $\mathrm{Df}$ & Cal. $\mathbf{r}$ & $\begin{array}{l}\mathrm{p}- \\
\text { level }\end{array}$ & Decision \\
\hline Creativity & 322 & 22.36 & 3.93 & 320 & .088 & .116 & $\mathrm{H} 0_{1}$ accepted \\
Self-concept & & 27.42 & .97 & & & & \\
\hline
\end{tabular}

The table 1 indicated the relationship between creativity and self-concept of students in Colleges of Education in Borno State. The analysis revealed a mean (X) of 22.36 and standard deviation (SD) of 3.93 with number (N) 322 for creativity and a mean(X) of 27.42 and standard deviation (SD) of .97 for self-concept with 322 numbers (N) of respondents. Observed $\mathrm{r}=.088$ at $\mathrm{P}<0.05$ level of significance for creativity and selfconcept respectively. The hypothesis which stated that there is no significant relationship between creativity and self-concept indicated a very low and positive relationship between creativity and self-concept of students, therefore; the null hypothesis was accepted.

$\mathrm{HO}_{2}$ : There is no significant relationship between creativity and academic achievement of students in Colleges of Education in Borno State.

Table 2: Mean standard deviation and ' $r$ ' value of creativity and academic achievement of students in Colleges of Education Borno State.

\begin{tabular}{lccccccc}
\hline Variable & $\mathbf{N}$ & $\mathbf{X}$ & SD & df & Cal. $\mathbf{r}$ & $\begin{array}{l}\text { p- } \\
\text { level }\end{array}$ & Decision \\
\cline { 2 - 8 } & & & & & & \\
Creativity & 322 & 22.36 & 3.93 & 320 & $.279^{* *}$ & .000 & $\mathrm{H}_{2}$ rejected \\
Academic act :evement & & 25.99 & 4.43 & & & & \\
\hline
\end{tabular}

** correlation is significance at 0.05 level (2-tailed)

The table 2 indicated the relationship between creativity and academic achievement of students in Borno State Colleges of Education. The analysis revealed a mean (X) of 22.36 and standard deviation (SD) of 3.93 with $(\mathrm{N}) 322$ for creativity and a mean(X) of 25.99 and standard deviation (SD) of 4.43 for academic achievement with $322(\mathrm{~N})$ of respondents Observed with $\mathrm{r}=.279^{*}$ at $\mathrm{P}<0.01$ level of significance for creativity and academic achievement. The hypothesis which stated that there is no significant relationship between creativity and academic achievement indicated a high and positive relationship between the two variables; therefore, the null hypothesis was rejected.

$\mathrm{HO}_{3}$ : There is no significant relationship between self-concept and academic achievement of students of Collages of Education in Borno State 
Table 3: Mean standard deviation and ' $r$ ' value of self-concept and academic achievement of students in Colleges of Education Borno State.

\begin{tabular}{|c|c|c|c|c|c|c|c|}
\hline Variable & $\mathbf{N}$ & $\bar{X}$ & SD & df & Cal. $r$ & $\begin{array}{l}\text { p- } \\
\text { level }\end{array}$ & Decision \\
\hline Self-concept & 322 & 27.42 & .99 & 320 & $.160^{*}$ & .004 & $\mathrm{HO}_{3}$ rejected \\
\hline Academic achievement & & 25.99 & 4.43 & & & & \\
\hline
\end{tabular}

Table 3 indicated the relationship between self-concept and academic achievement of students in Colleges of Education in Borno State. The analysis revealed a mean (X) of 27.42 and standard deviation (SD) of .99 with (N) 322 for self-concept and a mean (X) of 25.99 and standard deviation (SD) of 4.43 for academic achievement with 322 number (N) of respondents Observed with $\mathrm{r}=.160^{* *}$ at $\mathrm{P}<0.05$ level of significance. The hypothesis which stated that there is no significant relationship between self-concept and academic achievement, indicated a very high and positive relationship, therefore, the null hypothesis was rejected.

\section{Discussion}

The study revealed very low and positive relationship between creativity and selfconcept. The finding collaborated other findings such as those of Smith (1998) and Sears (1995) who reported that children of superior intellectual ability had higher self-concept and possessed higher ability to think in original and creative ways than children of lesser intellectual ability. The finding however was not in harmony with the findings of Sexton (1996) who found no significant relationship between self-concept and creativity. The significant relationship between creativity and self-concept of students of college of education in Borno State is in the area of possibility of a students to have all their needs in life such as cloths, books, shoes, shelter, pocket money and so on, this would help the student in developing positive self-concept and in turn student develop creative mind.

The study also found a low and positive relationship between creativity and academic achievement. This finding is in harmony with the findings of Karimi (2000) who found a low relationship between creativity and academic achievement among secondary school students in Shiraz school in Iran to be as low as 25\%. Haddon (1968) and Krause (1977) in separate studies also found low relationship between creativity and academic achievement. In relation to relationship between creativity and academic achievement of students of college of education in Borno State it revealed a low and positive relationship because of lack of properly utilizing their ability of creative thinking. This is clearly manifested on students during their teaching practice; they failed to use different methods of teaching different subjects or topics, they rather prepare to use only one method in teaching different subjects or topics, this would seriously contribute in a low relationship between the creativity and academic achievement of students of college of education in Borno State.

The study found that the relationship between self-concept and academic achievement was very high and positive. This finding contradicts the finding of Cokly (2000) who in 
his study on academic self-concept as it relates to academic achievement of African American College students attending predominantly white Colleges and Universities (PWCUs). The finding of the study was not in line with that of Gordon (1997) who in his study of the relationship among academic self-concept, academic achievement, and persistence with self-attribution, study pattern, and perceived school environment found a significant relationship among those variables. Students of college of education in Borno State satisfy some of their needs and that has led to develop positive self-concept and in the end the results revealed very high and positive relationship between the two variables.

\section{Recommendations and counselling implications}

Very low and positive relationship between students' creativity and self-concept was observed in hypothesis one. Guidance and counselling personnel should embark on a programme which could enhance their imaginary thinking activities involving sorting, sequencing, and selecting images of various objects through organizing remedial programme to strengthen their effort.

Low and positive relationship between students' creativity and academic achievement was revealed in hypothesis two.Another effective strategies must be taken by the college counsellor to improve and develop students utilization of their creative thinking, this kind of skills could be enhanced first, through fragmenting the whole into parts then conceiving all as one, for example a car could be seen as a whole after taking each part of a car (tires, starry, gear, wind screen etc.) which make the whole.

Very high and positive relationship between students' self-concept and academic achievement was obtained in hypothesis three.The college counsellor should provide strategies to maintain and sustained the relationship between their self-concept and academic achievement which is very good.

\section{References}

Akinboye, J.O. (2003). Creativity,innovation and success.Ibadan: Sterling Horden Publishers (Nig.) Ltd.

Child, R.R. (1977). Critical variables in effective counsellor training. Journal of CounsellingPsychology.16: (3): 238-245.

Cohen, B. \& Morrison, A.M. (2000).A school report on group counselling. Personnel and Guidance Journal.41 (21): 133-138.

Cookly, K. (2000).An investigation of Academic self-concept and its relationship toacademic achievement in Africa American Colleges studies.Journal of BlackPsychology,26 (2): 148-164.

Haddon, F. A., (1968). Teaching approach and the development of divergent thinking abilities inprimary schools.British Journal of Educational Psychology, 38: 171-180.

Guilford, D.(1959). A collaborative agenda for improving international studies in edu. Washington D.C National Academy Press

Kneller, F.H. (1965). Learning foundation for behaviour therapy. New York: John Wiley \&Sons. 
Krause, R.(1977). Productive (Productive thinking with children).Wenham, Germany. Beltz.

Mallim, K.R. \& Birch, R.F. (1997).A group programme for bright failing underachievers.Journal of College Student's Personnel,16 (3): 306-312.

Nadalmani, M.A. (2001). A study of family climate and self-concept in relation to academic achievement of students of secondary school, Unpublished M.Ed. Dissertation abstract, Kamataka

Nuthanap, G. (2007). Gender analyses of academic achievement among high school studentsUnpublished M.Ed. Dissertation University of Agriculture Dharwad.

Okoh, U. (1983). Motivational determinant in personality. New York: Oxford University Press.

Sandburg, R. \& Lubart, S. (1996). Creativity as the confluence of intellectual activity,knowledge, motivation, thinking styles: U.K. www.elsefier.com/locate/paid. Retrieved on $29 / 10 / 2011$

Salawu, A.A. (1998). Self-concept as it's relates to academic achievement of adolescents in secondary schools. Journal of Education and psychology in the third world. (JEPTWA) 1(1): 5-10.

Sidhu, K. (1987).Developing self-concept in children,Social Welfare, 34: 37-38

Smith, I. L. (1998).I.Q. creativity and achievement: Interaction and threshold. Multivariate Behavioral Research, 6: 51-62.

Tambawal, M.U. (2001). Relationships among self-concept, self-other motivation, and career maturity of teachers in tertiary institution in Sokoto State: Unpublished $\mathrm{PhD}$. Thesis Usmanu Danfodio University Sokoto

Tilley, W. (1994).Creativity in the science classroom:why it is essential as a microscope? The Science Teacher, 56 (2): 35-36. 